\title{
COVID-19 Pandemic and Comparative Health Policy Learning in Iran
}

\author{
Azam Raoofi, MSc ${ }^{1}$; Amirhossein Takian, MD, PhD ${ }^{1,2,3}$; Ali Akbari Sari, MD, PhD ${ }^{1}$; Alireza Olyaeemanesh, MD, PhD ${ }^{3,4}$; Hajar Haghighi, MSc ${ }^{1}$; \\ Mohsen Aarabi, MD, PhD ${ }^{5,6}$ \\ 'Department of Health Economics and Management, School of Public Health, Tehran University of Medical Sciences, Tehran, Iran \\ ${ }^{2}$ Department of Global Health \& Public Policy, School of Public Health, Tehran University of Medical Sciences, Tehran, Iran \\ ${ }^{3}$ Health Equity Research Center (HERC), Tehran University of Medical Sciences, Tehran, Iran \\ ${ }^{4}$ Department of Health Economics, National Institute of Health Research, Tehran University of Medical Sciences, Tehran, Iran \\ ${ }^{5}$ Azad University (IR) in Oxford, Oxford, UK \\ ${ }^{6}$ Department of Family Medicine, School of Medicine, Mazandaran University of Medical Sciences, Sari, Iran
}

\begin{abstract}
Background: On March 11, 2020, the World Health Organization (WHO) declared the novel coronavirus disease (COVID-19) a global pandemic. Starting in December 2019 from China, the first cases were officially announced on February 19 in Qom city, Iran. As of April 3, 2020, 206 countries have reported a total of 932166 cases with 46764 deaths. Along with China, USA, Italy, Spain, and Germany, Iran has been suffering the hardest burden of COVID-19 outbreak. Worse still, countries like Iran are struggling with the double burden of political sanctions to provide lifesaving medical equipment and medicines to combat the emergency.

Methods: Using systematic document content analysis and through the lenses of health policy triangle, this article aims to compare the policies and strategies that Iran is adopting, with the experience and recommendations of China and WHO to combat COVID-19.

Results: Iran has formulated contextual-based policies to combat COVID-19 outbreak before and after virus entrance. Insufficient whole-government, whole-society approach in managing the outbreak, inadequate lifesaving and protective equipment, and delayed decisive governance are the biggest challenges in policy making to combat COVID-19. COVID-19 policies are a public health concern and require professional advocacy attempts through appropriate inter-sectoral collaboration and whole-government coalitions.

Conclusion: COVID-19 is an unfolding outbreak; hence, policy learning is crucial to formulate appropriate policies and implement them accordingly. Iran has made many efforts to defeat the outbreak, but more coherent, timely and efficient action is required, now, more than ever, to save lives and slow the spread of this pandemic.

Keywords: COVID-19, Health Policy, Iran, Learning, Pandemic

Cite this article as: Raoofi A, Takian A, Akbari Sari A, Olyaeemanesh A, Haghighi H, Aarabi M. COVID-19 pandemic and comparative health policy learning in Iran. Arch Iran Med. 2020;23(4):220-234. doi: 10.34172/aim.2020.02.
\end{abstract}

Received: March 18, 2020, Accepted: March 21, 2020, ePublished: April 5, 2020

\section{Introduction}

Coronaviruses are a common family in humans and animals that usually cause respiratory and intestinal infections. Until the outbreak of the severe acute respiratory syndrome (SARS) in 2003 in China, and then the Middle Eastern coronavirus (MERS-CoV), this group of viruses were not considered as dangerous and uncontrollable. ${ }^{1-3}$ In December 2019, a novel coronavirus emerged in Wuhan, China, and has since spread rapidly to almost all countries around the world, with an increasing number of patients and victims of the disease. ${ }^{4,5}$

On December 31, 2019, the Health Commission of Hubei province in China reported 27 people with pneumonia of unknown cause. On January 7, 2020, Chinese authorities announced the identification of a new type of coronavirus. On January 11, the number of infected people increased to 41 and the first death due to the virus was reported. Chinese officials reported to the World Health Organization (WHO) that the disease was first seen among some people who sell seafood and live or fresh slaughtered animals. ${ }^{6}$ The first case outside of China was reported on 13 January in Thailand. ${ }^{5}$ With the death toll rising, on January 30, 2020, WHO declared a "Global Emergency" and on February 11 announced that the novel coronavirus would be called "COVID-19". The coincidence of the outbreak with the onset of the Chinese New Year and the peak travel time contributed to the widespread worldwide outbreak. Cases with mild clinical symptoms, and lack of appropriate infrastructure to isolate infected individuals, especially in low- and middle-income countries, are barriers to controlling the disease. ${ }^{5}$ On March 11, 2020, WHO declared the coronavirus outbreak a "Global Pandemic". 7 Following the ongoing spread of the disease, on March 16, the number of worldwide infected 
people exceeded that of China (Figure 1). ${ }^{8}$

On February 19, Iran confirmed two cases of death due to COVID-19 in the city of Qom, $150 \mathrm{~km}$ south of the capital city of Tehran. ${ }^{9}$ This was the first report of death officially diagnosed as COVID-19 in West Asia, Middle East and North Africa. ${ }^{10}$ Despite identification of the disease within a few weeks, measures to contain the pandemic have been insufficient. As of April 3, there were 932166 cases in 206 countries, of whom 46764 died and 214803 recovered. ${ }^{11}$ Figure 1 illustrates the chronological development of COVID-19 to date.

\section{COVID-19 in Iran}

Following its worldwide spread and two deaths in Qom city, on February 19, the Iranian officials announced the COVID-19 outbreak in the country. The Iranian Ministry of Health and Medical Education (MoHME) does not count any suspicious death prior to the above date as related to COVID-19. The virus spread was rapid in Iran and by March 5, 2020, all 31 provinces were infected. The total number of confirmed cases by April 3 was 53183 , with 3294 deaths and 17935 recoveries reported in Iran (Figure 2).

The coincidence of the COVID-19 pandemic and its alarming outcomes in Iran with the highest unilateral sanctions imposed by the United States against Iran has posed many obstacles to the country's health sector, ${ }^{12}$ which is one of the most efficient and resilient health systems in the Eastern Mediterranean region, ${ }^{13}$ to combat against virus. This has led to scaling up the burden of the epidemic and the number of casualties. ${ }^{12}$

World Health Organization Actions in Response to the Outbreak

Following the global emergency of COVID-19, WHO in collaboration with the United Nations (UN) SecretaryGeneral, has launched daily reports on the epidemical situation of the disease and COVID-19 Strategic Preparedness and Response Plan (SPRP) with the aim of providing a practical guide for member states to develop a Country Preparedness and Response Plan (CPRP) to the COVID-19 outbreak. ${ }^{14}$ Subsequently, on February 16-24, 2020, WHO formed a joint mission to provide rapid information at national (China) and international levels for future action in response to the ongoing outbreak of COVID-19 and the readiness of countries not yet infected with the virus. The results of the joint mission work in China were provided in the form of recommendations in five key areas that are presented in Table $1 .^{15}$

In a joint statement with the World Tourism Organization (WTO), WHO also made recommendations to guide travel in response to COVID-19. ${ }^{16}$ Moreover, WHO has set up an Operations Supply and Logistics team consisting of various experts to advise and improve the management and coordination of information and to monitor and evaluate member states' actions and to provide medical, laboratory and protective equipment to these countries. ${ }^{17}$ The group travelled to Iran on March 2, 2020 to work

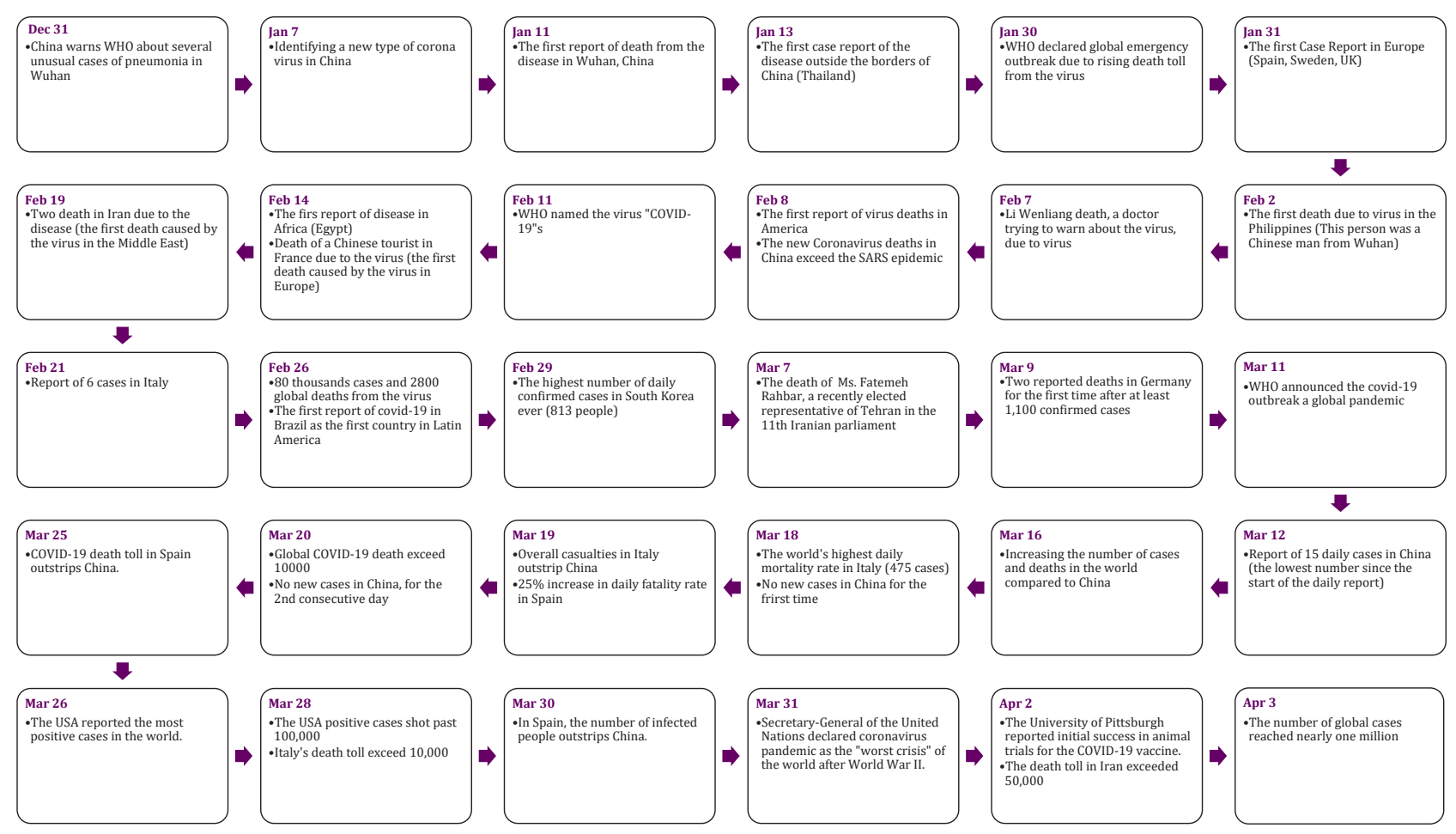

Figure 1. COVID-19 Spread Timeline. 




Figure 2. Confirmed Cases and Deaths Due to COVID-19 in Iran.

with Iranian health authorities to prepare for the battle against COVID-19 in Iran with a cargo of medical and personal protective equipment. ${ }^{18}$

During a media briefing on March 5, the DirectorGeneral (DG) of WHO stated that the epidemic can be reversed only by using a coherent and holistic approach and utilizing all government capacities. He emphasized on a whole-government approach, not only the Ministry of Health, to defeat the pandemic. The DG mentioned that the epidemic control programs initiated with leadership from the top and require coordination of all government sectors such as security, diplomacy, finance, commerce, transport, trade, information, etc. He also expressed concern about the level of political commitment in some countries that

Table 1. The Joint Mission Recommendations in Response to COVID-19 Outbreak

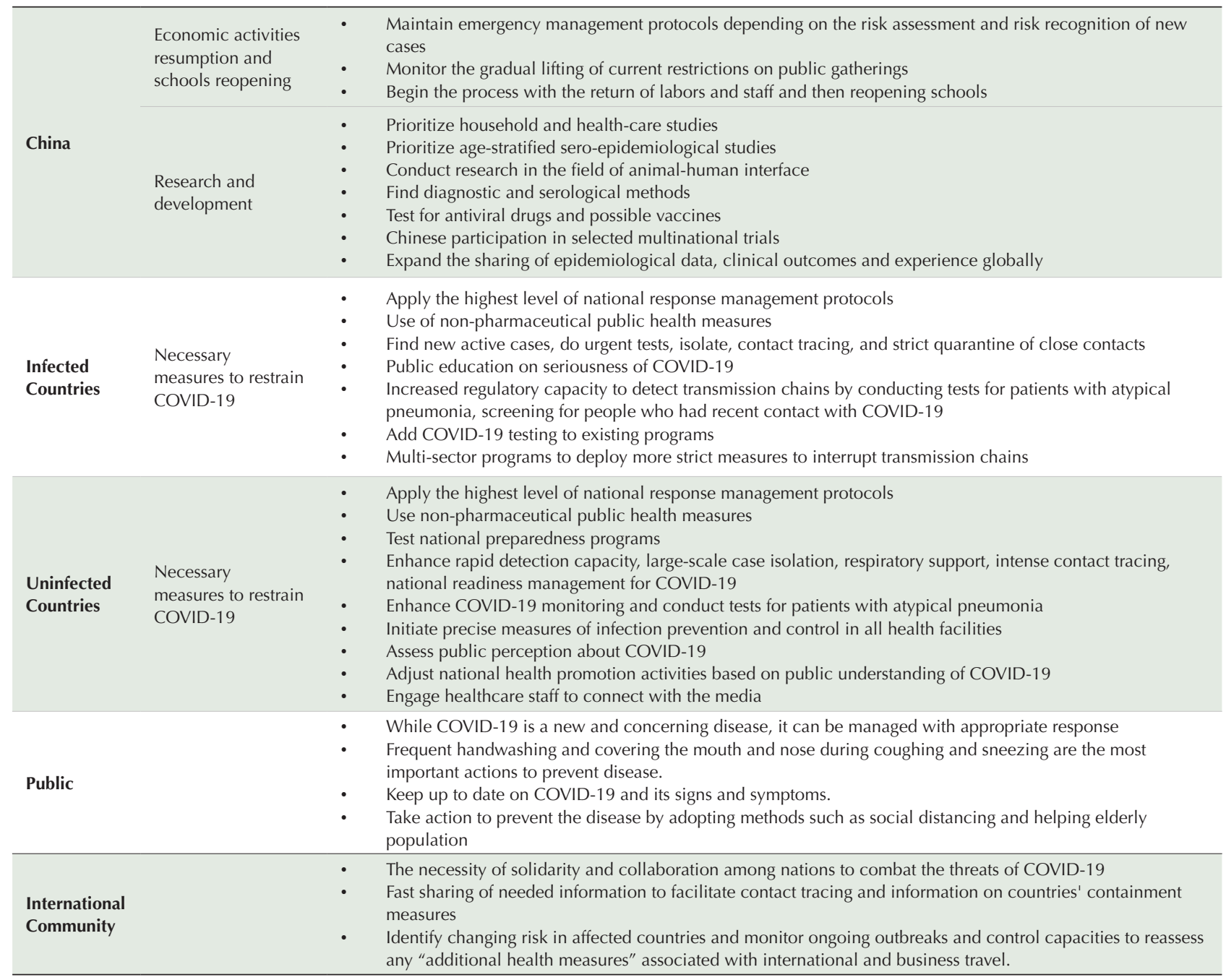


does not match the extent of the threat. ${ }^{19} \mathrm{WHO}$ is holding regular briefings on COVID-19 and continues knowledge and advice sharing with member states. On March 20, 2020, WHO launched an official social media channel on WhatsApp to educate the public. ${ }^{20}$ It has reached out to many influential individuals and organizations, e.g. FIFA, to establish a fund for donations. On March 25, 2020, along with the UN Secretary General, the Executive Director of the UNICEF, WHO DG launched Global Humanitarian Response Plan (GHRP) to help contain the spread of virus mainly through assisting poor countries. ${ }^{21}$

Chinese Government's Response to the Outbreak

Following the observation of cases of pneumonia of unknown etiology in Wuhan, the State Council and the Central Committee of the Chinese Communist Party announced emergency in the country. The State Council formed a Central Leadership Group for Epidemic Response. The State Council Secretary-General personally took over the leadership of the group and called for the prevention and control of the COVID-19 outbreak to be the government's top priority at all levels. Vice Premier has also coordinated the front line of prevention and control of outbreaks. Prevention and control measures were quickly implemented in Wuhan and other areas of the Hubei province and then throughout the contaminated areas. The measures were carried out during three stages within two major events. First, on January 20, COVID-19 was placed on the list of Class B infectious diseases that need to be quarantined. Thus, the disease control approach changed from partial control to comprehensive control measures in accordance with the law. The second event was the issuance of a State Council notice on February 8 about the need to resume enterprises activities. The announcement indicated that China's national epidemic control activity had entered the overall control and prevention phase, with the restoration of social and economic activities to its origin. The first stage of measures, before January 19, focused on preventing people from leaving Wuhan and other suspected areas of the Hubei province and preventing people from entering from other provinces, with the overall goal of controlling the source of infection and preventing the transmission and spread of the virus. In the second stage, from January 20 to February 7, measures were conducted to reduce the severity of the epidemic and reduce its transmission rate, and in the third stage, after February 8 , a set of measures were implemented to reduce affected clusters, complete disease control, balance between prevention and control of the epidemic, sustainable socioeconomic development, integrated command, standard guidance and implementing evidence-based policies. ${ }^{15}$ Figure 3 illustrates epidemic COVID-19 curve concurrent with major countermeasures in China.

Countries' Preparedness for Dealing with Biological Epidemic

The first report in the world to assess 195 countries was published in 2019 by Johns Hopkins University. ${ }^{22}$ Table 2 shows the situation of Iran compared to other countries. According to this ranking model, Iran was judged not to be ready enough to face biological threats. However, the current progression of COVID-19 outbreak in the US and its all-encompassing consequences proved the significant flaws in this scoring method and therefore the conclusions derived from it.

Iranian Policy Analysis in Response to the Outbreak Beginning of the epidemic in China was a serious threat

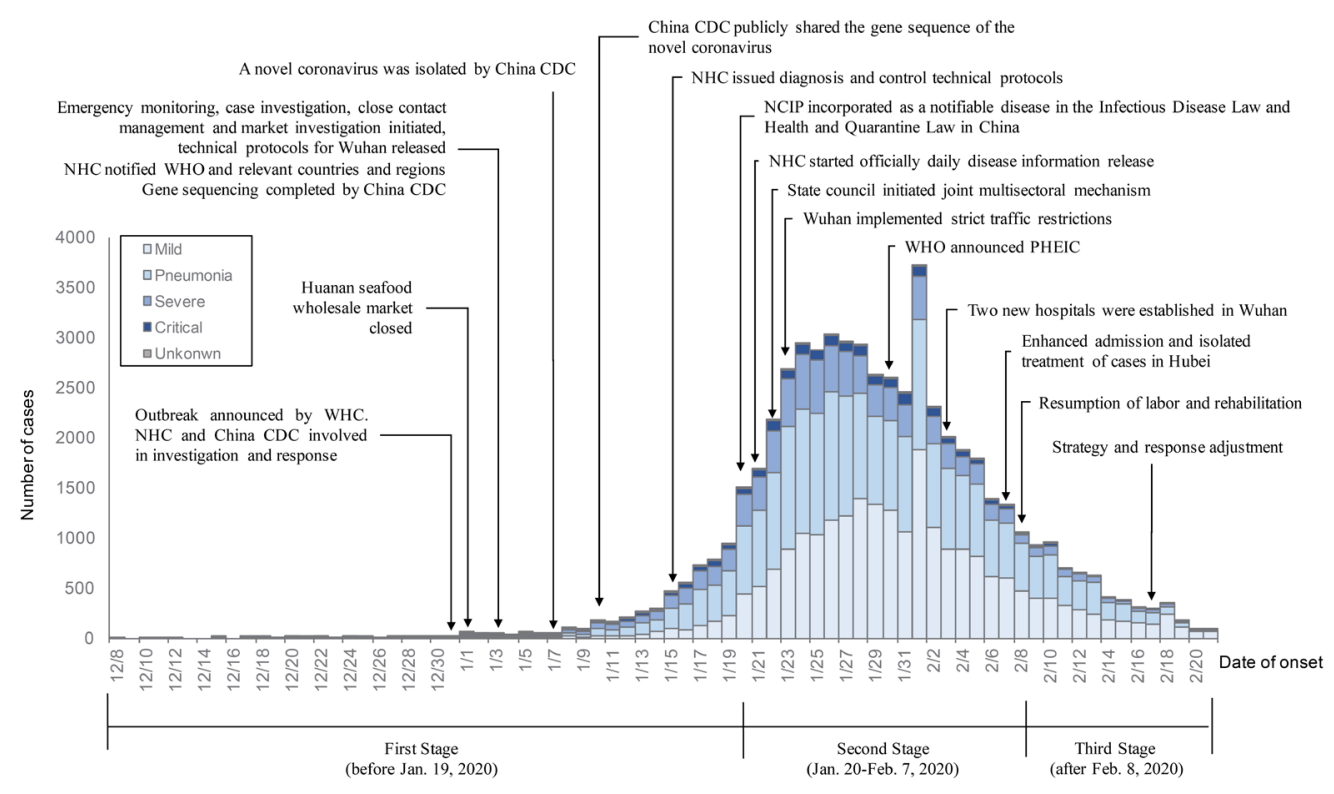

Figure 3. Epidemic COVID-19 Curve Concurrent with Major Countermeasures in China (From Report of the WHO-China Joint Mission on Coronavirus Disease $\left.2019^{15}\right)$. 
Table 2. Countries Preparedness Against Epidemics (out of 195 Countries)22

\begin{tabular}{|c|c|c|c|}
\hline & First Score (Country) & Average Score & Iran Score (Rank) \\
\hline Overall score & 83.5 (USA) & 40.2 & $37.7(97)$ \\
\hline 1. Prevention of the emergence or release of pathogens & 83.1 (USA) & 34.8 & $44.7(52)$ \\
\hline 2. Early detection \& reporting for epidemics of potential international concern & 98.2 (USA) & 41.9 & $37.7(103)$ \\
\hline 3. Rapid response to and mitigation of the spread of an epidemic & 91.9 (UK) & 38.4 & 33.7 (109) \\
\hline 4. Sufficient \& robust health system to treat the sick \& protect health workers & 73.8 (USA) & 26.4 & $34.6(62)$ \\
\hline 5. Commitments to improving national capacity, financing and adherence to norms & 85.3 (USA) & 48.5 & $28.7(186)$ \\
\hline 6. Overall risk environment and country vulnerability to biological threats & 87.9 (Liechtenstein) & 55 & $50.3(124)$ \\
\hline
\end{tabular}

to other countries, including Iran. Formulation and implementation of timely and appropriate policies to prevent the import of coronavirus into the country has been of utmost importance. Policy analysis enables us to evaluate various stages of the policy and to identify its strengths and weaknesses, which in turn may facilitate evidence-informed policymaking. In this study, using health policy triangle, ${ }^{23}$ we analyzed the policies of fighting against COVID-19 in Iran compared with the recommended polices of $\mathrm{WHO}$ and China.

\section{Materials and Methods}

This is a qualitative study. We used a purposeful content analysis of available policy documents, programs, action plans, reports, websites and official news related to COVID-19 in Iran (mostly the MoHME), China and the WHO. A deductive approach was used to extract and analyze data, which was further evaluated by four experts in this field (AT, AAS, AO and MA) in accordance with the adopted conceptual framework. We also obtained the experts' opinions on all aspects of the applied conceptual frameworks to criticize and refine findings. Finally, we compared Iran's measures with China's and WHO guidelines, and interpreted the challenges to provide evidence-informed policy solutions. Categorical content analysis was used to extract data in this study, such that the results of experts' opinion and documents analysis were coded into categories related to the elements of the applied conceptual frameworks.

The Conceptual Framework

Our conceptual framework had three main dimensions. First, health policy triangle was used to analyze the content, context, process and main actors involved in design, agenda setting and implementation of related policies. ${ }^{23}$ We also used the Hall Model (legitimacy, feasibility and political support) to describe the components of agenda setting. ${ }^{24}$ Finally, we combined top-down and bottomup implementation theories (synthetizing approach), i.e. the principle-agent theory and the advocacy coalition framework to explain the gap between the desired policies and their implementation ${ }^{25,26}$ (Figure 4).

\section{Policy Content}

In response to the COVID-19 epidemic, Iran's policy content can be divided into two categories: pre-epidemic and post-epidemic measures.

\section{Measures before the Official Declaration of the COVID-19 Epidemic in Iran}

Despite the widespread outbreak of the disease in China and predictions and precautions of possible entrance of the virus to Iran, Iran's response for preparedness and prevention was not timely and quick enough for virus containment and risk mitigation. In general, the government of Iran planned for the following three steps

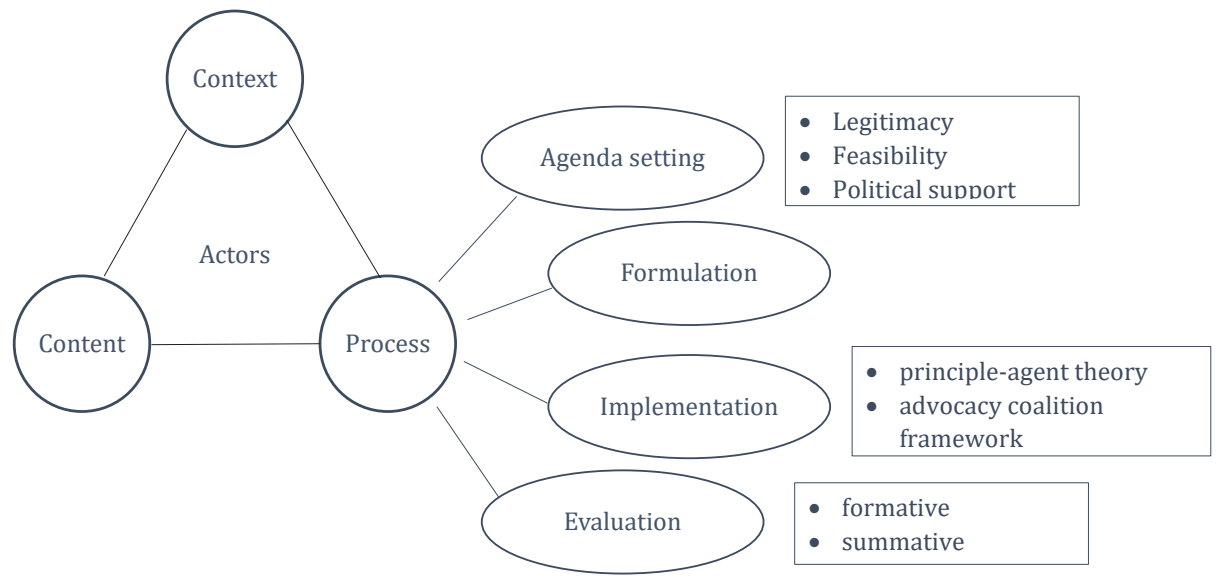

Figure 4. Applied Conceptual Framework. 
prior to the outbreak:

1- Examination of incoming passengers from China and transferring suspicious cases to designated hospitals;

2- Returning the Iranian students residing in China and quarantining them for two weeks;

3- Allocation of specific funds for provision of necessary resources, i.e. personnel, medicines, equipment, etc.

Measures after the Official Declaration of the COVID-19 Epidemic in Iran

We classified Iran's measures at this stage based on WHO six building blocks (Table 3).

\section{Policy Context}

Contextual factors in response to this epidemic in
Iran include situational, structural, socio-cultural and international factors. The widespread prevalence of the disease and high causalities have made COVID-19 policies a high priority, leading to attract a great deal of resources and inter-sectoral collaboration. ${ }^{25}$ Likewise, the structural factors including: the collaboration of other organs such as the municipality; the educational role of media to raise public awareness regarding health promotion and prevention, the use of required technologies; the existence of a comprehensive data collection system and reporting from low to high levels, are influencing these policies..$^{25,27}$ Socio-cultural factors, e.g. the role of religious scholars in policymaking and implementation of formulated policies as well as relatively low level of public health literacy play major roles in Iran. ${ }^{28}$ In addition, international

Table 3. Chronological Timetable of Iran's Activities after COVID-19 Outbreak, in Line with WHO Six Building Blocks

\begin{tabular}{|c|c|c|}
\hline $\begin{array}{l}\text { Building } \\
\text { Blocks }\end{array}$ & Domain & Selected Main Activities \\
\hline \multirow{3}{*}{ Governance } & Policymaking & 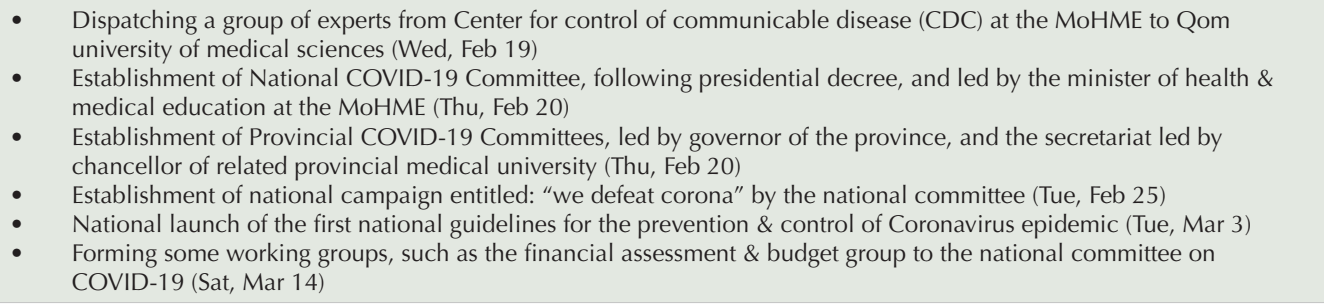 \\
\hline & $\begin{array}{l}\text { Inter-sectoral } \\
\text { collaboration }\end{array}$ & $\begin{array}{l}\text { - } \quad \text { Establishment of COVID-19 health headquarter within the armed forces, following supreme leader decree (Thu, Mar 12) } \\
\text { - } \quad \text { Ministry of Defense to accelerate supply of COVID-19 equipment (Thu, Mar 5) } \\
\text { Disposal of hospital waste related to COVID-19 patients by scientific and safe methods, with safe devices in isolated } \\
\text { - } \quad \text { Shi'ite mainstream clergy decrees the need to avoid mass gathering during the COVID-19 outbreak (Sun, Feb 23) } \\
\text { - } \quad \text { Issuing health certificates for foreign travelers in coordination with the MoHME \& International Cooperation Office } \\
\text { across most international airports (Sun, Feb 23) } \\
\text { - } \quad \text { Burial procedures announced under the supervision of the environmental health units in each province (Mon, Feb 24) } \\
\text { - } \quad \text { Prmed forces hospitals preparedness for emergency admission of COVID-19 patients (Wed, Feb 26) } \\
\text { - } \quad \text { National \& international non-governmental organizations (NGO) preparedness to assist COVID-19 control in Iran (Mon, } \\
\text { - } \quad \text { Dar 2) } \\
\text { - } \quad \text { Expinfecting Tehran, Qom and Guilan provinces by the Ministry of Defense (Fri, Feb 28) } \\
\text { Developing a set of protocols for the Ministry of Defense \& the armed forces to protect soldiers and prevent } \\
\text { vulnerabilities in barracks (Sun, Mar } 1 \text { ) } \\
\text { Presidential decree for maximum cooperation of all trusted agencies and ministries with the national committee and the } \\
\text { MoHME to fight against Coronavirus (Tue, Mar 10) } \\
\text { - } \quad \text { Cxpanding free third party insurances for two months (Wed, March 11) } \\
\text { Concluding memorandum of understanding on producing protective cloths for corona health \& medical personnel in } \\
\text { cooperation with the foreign currency board-MoHME; Ministry of Industry, Mines and Trade; national medical device } \\
\text { directorate, Iranian textile and garment manufacturing and export union (Fri, Mar 13) } \\
\text { Providing unemployment insurance to workers of closed workshops (Sun, Mar 15) } \\
\text { Reducing clearance time for new equipment to fight against coronavirus from Imam Khomeini Airport Customs (Mon, } \\
\text { Mar 16) }\end{array}$ \\
\hline & Legislation & $\begin{array}{l}\text { - Necessity of providing full time services and medical supplies during formal and informal holidays (Wed, Mar 4) } \\
\text { - } \quad \text { Notice of the systematic distribution of examination and surgery gloves (Fri, Mar } 6 \text { ) } \\
\text { Providing solutions for legal treatment and offenses and penalties for people with coronavirus who conceal symptoms } \\
\text { or fail to comply with health standards (Thu, Mar 7) } \\
\text { - } \quad \text { Approval of convening the national committee on COVID-19 meetings through video conference (Thu, Mar 7) } \\
\text { - } \quad \text { Extension of third-party after-sales service licensing and quality control of companies whose licenses have expired for } \\
\text { three months (Wed, Mar 11) } \\
\text { Validity of ordinary and urgent registration files for all IRC codes and issued manufacturing licenses that expire on } \\
\text { - } \quad 1 / 03 / 1399 \text { (Thu, Mar 12) } \\
\text { Notice for supply and distribution of the mask for public access and supply at the pharmacy level by the head of FDO } \\
\text { (Thu, Mar } 12 \text { ) } \\
\text { Notice for immediate preparation of medical equipment and supplies requirement for facing COVID-19 from the } \\
\text { national medical device directorate (Fri, Mar } 13 \text { ) } \\
\text { Extending the use of patient record by the Iranian health insurance organization for repeat prescription to reduce } \\
\text { unnecessary travel (Sat, Mar 14) }\end{array}$ \\
\hline
\end{tabular}


Table 3. Continued

\begin{tabular}{|c|c|c|}
\hline $\begin{array}{l}\text { Building } \\
\text { Blocks }\end{array}$ & Domain & Selected Main Activities \\
\hline & License & $\begin{array}{l}\text { - } \quad \text { Licensing the import of all types of masks with a minimum tariff (Fri, Mar 6) } \\
\text { Easing rules for medical universities with permission to recruit new personnel, bypassing some of the most difficult and } \\
\text { cumbersome rules and temporary purchases required by forming a three-member committee (Fri, Feb 28) }\end{array}$ \\
\hline & $\begin{array}{l}\text { Prohibitions \& } \\
\text { restrictions }\end{array}$ & 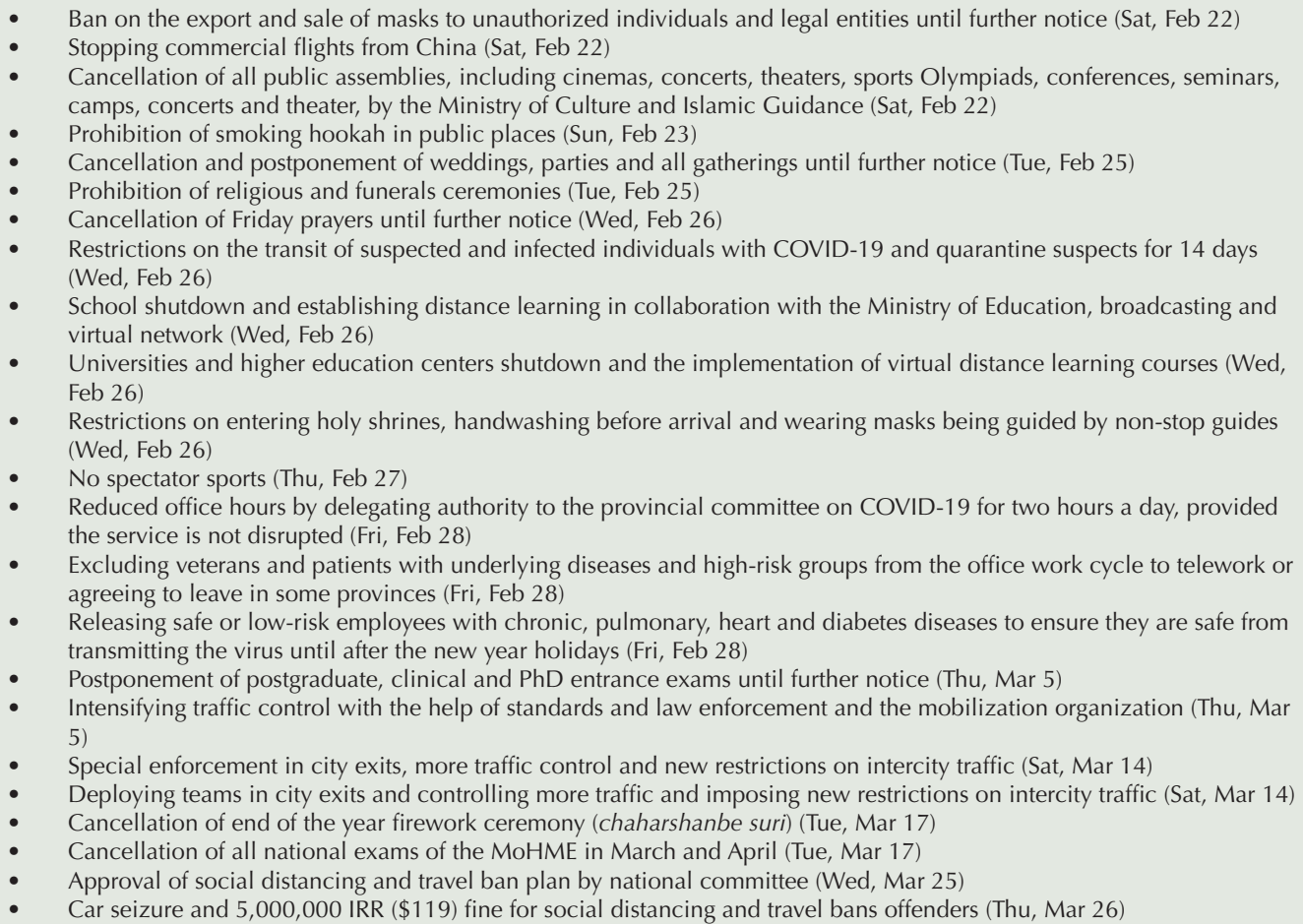 \\
\hline
\end{tabular}

- $\quad$ Preparing and equipping hospitals and health centers (Wed, Feb 19)

- Designating selected MoHME hospitals to COVID-19 patients (Wed, Feb 19)

- Allocation of special ambulances and specific protective cloths for health workers (Wed, Feb 19)

Preparation, equipping

\& setting-

up health

centers and

ambulances

Service

delivery

Financing
Preparation and equipping para-clinic centers

Public places disinfection

Insurance

Resource allocation
- Distribution of health packages includi
and in front of homes (Sun, Feb 23)

- Establishment of 22 corona clinics in Tehran to facilitate work and prevent congestion in hospitals (Mon, Feb 24)

- Allocating selected 16-hour centers (4 AM to $12 \mathrm{AM}$ ) to the universities in the Tehran province and stand-by ambulances near selected centers for rapid dispatching of eligible patients (Wed, Feb 26)

- Requirements of all medical institutions and physicians' offices according to the routine procedure of the MoHME (Tue, Mar 3)

- $\quad$ Launching psychological call centres (Dial 4030) (Sat, Mar 14)

- $\quad$ Establishment of nursing care center to admit COVID-19 patients after discharge in Qom and Tehran (Mon, Mar 16)

- Delivery of 63 advanced ambulances to the MoHME (Tue, Mar 17)

- Ministerial decree to employ Iranian medicine in the prevention and treatment of COVID-19 (Sun, Mar 22)

- $\quad$ Launching more than 20 COVID-19 diagnostic laboratories across the country (Wed, Feb 26)

- Launching Coronavirus diagnostic laboratories in Gilan province (Mon, Mar 2)

- Increasing the number of coronavirus diagnostic laboratories to 50 centers in Iran (Thu, Mar 5 )

- Launching new coronavirus detection lab at Pasteur Institute of Iran and increasing its coronavirus diagnostic capacity up to 1800 tests per day (Sat, Mar 14)

- $\quad$ Adding 3,000 hospital beds to the Iran Mall Exhibition Center (Mon, Mar 23)

- Opening 2000-bed army hospital and recovery complex in permanent location of Tehran international exhibitions

- $\quad$ Extensive daily disinfection of large shopping malls, subways and city bus lines (Sat, Feb 22)

- Providing disinfectants in subways and other public places (Sat, Feb 22)

- Purchasing all masks produced locally, by the MoHME, to be distributed free of charge among citizens at risk (Sat, Feb 22)

- $\quad$ Providing free healthcare services to people hospitalized with clinical symptoms and suspected COVID-19 cases with positive lab results (Sun, Mar 1 )

- $\quad$ Automatic and free renewal of Iranian health insurance coverage for two months (Wed, Mar 4)

- $\quad$ Reducing the time of affordability assessment for COVID-19 patients from one month to 24 hours (Sat, Mar 14)

- $\quad$ Free extension of social security insurance for two months (Mon, Mar 16)

- $\quad$ Corona Economic Committee asks supreme leader to permit allocation of additional \$1 billion from National Development Fund towards the outbreak (Thu, Mar 26)

- Allocating more than 7,708 billion IRR $(\$ 183,524)$ by the president of Iran to compensate salaries of frontline healthcare providers in the fight against Coronavirus (Sat, Feb 29)

- Charity donation to Pasteur Institute in Iran to increase its capacity to deal with COVID-19 (Sun, Mar 8)

- The MoHME established a fund to collect donations for prevention and fight against coronavirus (Monday, March 16

- The MoHME requested the president for 250 million euros extra and urgent budget to be spent on treatment of coronavirus patients and provision of hospital clothing, masks and equipment (Tue, Mar 17)

- $\quad$ Release of charity bonds with Corona 1 and Corona 2 symbols to raise funds (Wed, Mar 18) 
Table 3. Continued

\begin{tabular}{|c|c|c|}
\hline $\begin{array}{l}\text { Building } \\
\text { Blocks }\end{array}$ & Domain & Selected Main Activities \\
\hline $\begin{array}{l}\text { Health } \\
\text { workforce }\end{array}$ & $\begin{array}{l}\text { Recruitment } \\
\text { \& human } \\
\text { resource } \\
\text { supply }\end{array}$ & 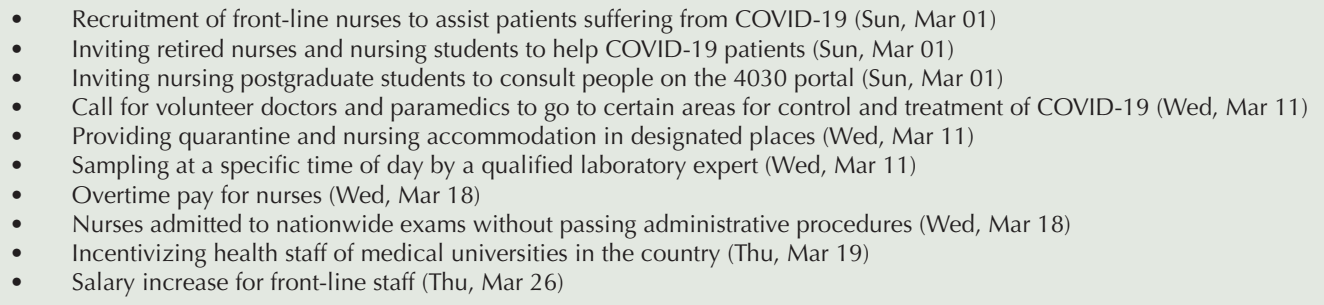 \\
\hline \multirow[t]{3}{*}{$\begin{array}{l}\text { Information } \\
\text { \& research }\end{array}$} & $\begin{array}{l}\text { Informing \& } \\
\text { raising public } \\
\text { awareness }\end{array}$ & 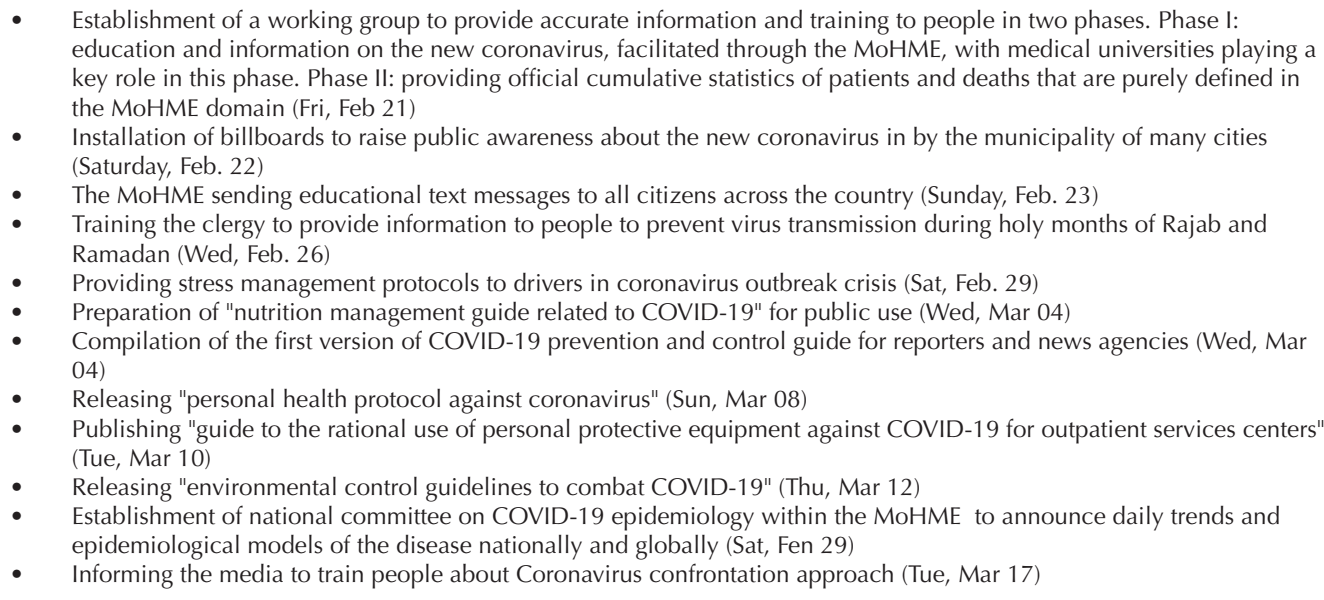 \\
\hline & Research & $\begin{array}{l}\text { - } \quad \text { Emphasis on comprehensive research on COVID-19 (Mon, Mar 10) } \\
\text { Allocation of specific and fast track funds to medical universities for conducting research on various aspects of } \\
\text { COVID-19 (Mon, Mar 23) } \\
\text { - Guidelines for necessity to obtain IRCT code for clinical trials on COVID-19 (Tue, Mar 24) } \\
\text { - Iran joins WHO to conduct various rapid clinical trials on treatment protocols on COVID-19 (Tue, Mar 24) }\end{array}$ \\
\hline & $\begin{array}{l}\text { Information } \\
\text { technology \& } \\
\text { system }\end{array}$ & $\begin{array}{l}\text { - } \\
\text { - } \\
\text { Deploying } 4030 \text { call center nationwide to boost speed in responding to people's queries about COVID-19 (Wed, Feb. } \\
\text { - } 26 \text { ) } \\
\text { Establishment of Iran health insurance call center to respond to people's queries about COVID-19 (Sat, Feb 29) } \\
\text { Launching two new systems, volunteer registration system for coronavirus management and control and nurses' direct } \\
\text { communication system with nursing assistant, the MoHME (Sun, Mar 1) } \\
\text { - } \quad \text { Launching a self-reporting system to identify suspicious cases and control infected cases (Wed, Mar 11) } \\
\text { - Launching the coronavirus website (Friday, March 20) } \\
\text { Launching the application of nutrition, safety and corona (TAC) (Sun, Mar 22) }\end{array}$ \\
\hline $\begin{array}{l}\text { Medical } \\
\text { products \& } \\
\text { technologies }\end{array}$ & $\begin{array}{l}\text { Medicines } \\
\text { and medical } \\
\text { equipment }\end{array}$ & $\begin{array}{l}\text { - } \quad \text { Daily supply of } 4000 \text { integrated clothes for health staff (Fri, Mar 6) } \\
\text { - } \quad \text { Dispatching } 1.253 \text { million pack of supplies to Guilan province (Sat, Mar 17) } \\
\text { - } \quad \text { Dispatchion of Coronavirus transmission environment by Pasteur Institute of Iran (Tue, March 10) } \\
\text { Mar 12) } \\
\text { - } \quad \text { Delivery of } 250000 \text { liter of disinfectant material to medical universities across the country (Sun, Mar 15) } \\
\text { Rationing \& distribution of medical masks for medical centers (Mon, 26 Mar) }\end{array}$ \\
\hline
\end{tabular}

organizations such as the WHO, other UN agencies and a few countries have been providing some assistance during the COVID-19 outbreak in Iran. ${ }^{25}$

\section{Policy Actors}

Actors include a wide range of governmental and nongovernmental organizations, interest groups, media, religious groups, etc, that influence various stages of the policy process. Actors' interaction with each other can lead to conflicts of interest. The MoHME, as the stewardship of health, is the key actor in the fight against COVID-19 in Iran. The Universities of Medical Sciences (UMS), the MoHME various deputies (particularly
Deputies for Curative Affairs, Public Health, Nursing, and Administration and Finance), Food and Drug Organization, Emergency Services Organization, and Iran Health Insurance Organization are the main intraorganizational actors within the MoHME, plus almost 200 Medical Associations, General Medical Council, General Nursing Council, Social Security Organization (and other insurance organizations), are also among main actors in policymaking, implementation and evaluation of related policies.

The main extra-organizational actors in COVID-19 policy are the Islamic Consultative Assembly (Parliament), Cabinet of Ministers and Planning and Budget 
Organization (PBO), which play key role in policymaking process through lawmaking, legislation, regulation and budget allocation. The religious schools (Hawza Elmieh) are playing a critical role in closure of religious places such as mosques and holy shrines, the judiciary system helps temporary release of tens of thousands of prisoners, the armed forces are helping in establishment of mobile hospitals and enforcing law to perform curfew and city lockdown while preserving security, the national TV and the Media are in charge of increasing public awareness, other ministries, trade unions, NGOs, the civil society, scholars and academics, celebrities, among other players are all involved in the campaign against COVID-19.

\section{Policy Process}

\section{Agenda-Setting}

Given the significant impact of COVID-19 on the whole society, which is rapidly increasing, the policies to combat the situation have been legitimate enough to be pushed into agenda. The feasibility of some policies, e.g. quarantine, city lockdown and curfew has been subject to doubt until recently. This was partially due to concerns about the logistics of keeping people inside and the perceived risks of such measures. Hence, political support for restricting policies, i.e. social distancing measures, was diverse. It was on March 25, 2020, that the national committee on COVID-19, led by the president, showed reasonable political support and decided to scale up the strategies to keep more people inside. The pathway of events that led to this turning point was long and fed by campaigns led by known scholars, academics, politicians, etc, as well as the unfolding experience of other countries that did the same. Since the policy began to be executed in the middle of Persian New Year holiday, when most people travelled, its execution was challenging and needed extra force. Nevertheless, since most facilities and social activities are shut down, uncertainties still remain about the possible length of social distancing and public compliance, in case it is necessary to keep them for the long run.

In formulating action plans and policies, it is crucial to take into consideration the capacity of medical universities and their ability to implement programs. ${ }^{28}$ Reliable and up-to-date statistics, information, and evidence as well as affordable solutions are essential in formulating these policies. Moreover, educational materials and a set of guidelines are necessary for service providers. Given the complexity of the issue and the necessity of inter-sectoral collaboration, formal multidisciplinary working groups are recommended to provide appropriate solutions. In this regard, the national committee on COVID-19 within the MoHME needs strengthening to enjoy the experience and expertise of a wider group of stakeholders from scientific, civil society and executive backgrounds. Knowledgeable scholars in health economics, management, policy, environmental health, disaster management and other specialties are essential to be part of the committee to help formulate policies based on inter-sectoral collaboration, which can in turn make the programs and policies more efficient and feasible.

\section{Policy Implementation}

Implementation is a complex and interactive process that is often overlooked and largely depends on other dimensions of the policy. ${ }^{25}$ Evidence suggest that the attitudes, strategies and knowledge of front-line staff informally influence policy implementation. Inappropriate working conditions such as high workload and sudden increase in referrals due to the widespread epidemic, insufficient human resources and intensive shifts, stressful and high risk working environment in the outbreak, financial constraints, limited resources and inadequate protective equipment, inadequate staff training and income, conflicts between employees' personal interests, their sense of altruism in dealing with COVID-19 patients and their professional commitment are among the biggest barriers to appropriate implementation of COVID-19 policies. According to Lipsky's bottom-up approach, implementation of policies is mainly influenced by frontline staff, the so-called street-level bureaucrats (SLBs). ${ }^{29}$ In the battle against COVID-19, SLBs are physicians and nurses who are in direct contact with patients and therefore, understand their needs better. To optimize service delivery and achieve the best possible results, regular negotiation between policy-makers and SLBs is crucial. ${ }^{25}$ Given the rapidly unfolding experience of COVID-19 pandemic and frequent changes in related policies, the top-down approach in implementation is inevitable. The time gap between the coronavirus outbreak in China and its spread in Iran could have provided the Iranian policymakers with a good opportunity for policy learning. Moreover, most policies related to COVID-19 are redistributive, and very difficult to implement. ${ }^{30}$

From the perspective of principle-agent theory, service providers (agents) have the freedom to act in policy implementation and may not even find themselves involved in fulfilling the demands of the principles (government and ministry of health). ${ }^{25}$ Information asymmetry between principles and agents is an important contributing factor in the complexity of relationship between them. ${ }^{31}$ COVID-19 policies are inherently macro, complex, ambiguous, multi-causal, sensitive, and costly, and implementing them in the Iranian context, with several underlying factors and restrictive complexities, i.e. the US unilateral sanctions against the country, ${ }^{12}$ is difficult. Therefore, the government needs to monitor and evaluate front-line staff at reasonable costs. Providing financial and non-financial incentives for agents on one hand, and eliminating the financial relationship between the recipients of healthcare services and agents on the other hand, are effective solutions to improve the 
relationship between the principle (the MoHME and UMSs) and agents. This is more applicable to agents (doctors and nurses) who have been called as temporary back up to front-line personnel in heavily affected areas of the country.

The policy process can be viewed as a competitive and interactive process between a coalition of actors and stakeholders who seek support for their existing problem and implement solutions based on their belief systems. ${ }^{32}$ These coalitions are groups of actors (locally, nationally, internationally, government, economic, civil society, journalists, researchers, and policy analysts) with similar beliefs, usually formed as informal groups with the aim of persuading policymakers to reform a policy. ${ }^{32}$ The dynamics of a pro-opposition coalition is important. Thus, a policy that is actually a by-product of the dominant coalition belief system, emerges as a result of conflicts and negotiations between different coalitions of actors in the policy subsystem. ${ }^{33}$ Also, advocacy coalition framework emphasizes the importance of the role of policy brokers who, as mediators or political intermediaries, seek to make a compromise and limit differences between coalitions to reach agreement. $^{25}$

COVID-19 policies are of significant public health concern that require complex inter-sectoral collaboration and government agreement through various coalitions. Evidence suggests that an advocacy coalition framework works well on issues where there is severe divergence of views or possibly a political deadlock between stakeholders. This framework helps policymakers to find out solutions for policy conflicts by understanding the causes of these conflicts and thus making the best decisions to overcome coronavirus. ${ }^{25}$ We recommend the formation of several coalitions consisting of both advocates and opponents on Iran's COVID-19 policies. The actors in these coalitions may include, but are not limited to, various individuals and groups with different belief systems, including religious groups, parliamentarians, governors, academics, municipalities, the armed forces, ministries, NGOs, etc. The presence of an experienced and well-regarded member, such as the first vice president, as a policy broker in the coalitions may enhance the political weight of the task force. Some multi-dimensional faith-based decisions, such as the quarantine of Qom city, closure of holy shrines and cancellation of Friday prayers to enforce social distancing, are among difficult measures, deciding which may benefit from coalition building. The first vice president as a policy broker and other stakeholders including the clergy, governors, mayors and Friday imams of Qom and Mashhad, member of parliamentarians plus some experts and academics could be the members of such a coalition.

\section{Policy Evaluation}

Periodic and regular evaluation based on evidence-based criteria, is essential in improving ongoing policies that are implemented in combatting COVID-19 in Iran. Since policies are subject to rapid change, summative evaluation is not a feasible option in the initial stages, ${ }^{34}$ albeit the number of new cases, recoveries and death are announced by the MoHME everyday. ${ }^{35}$ Rather, formative evaluation is required to enhance the chance of better policy making and improve existing policies. ${ }^{34}$ Evaluation begins before policy formation and continues throughout the life of policy during and after implementation. ${ }^{25}$ Although the visit of WHO delegation (March 2, 2020) was a crosssectional external evaluation that provided insightful recommendations to improve practices and receive up to date information on ways to contain and mitigate the outbreak, more ongoing formative evaluation, both internally and externally, is required to improve practices. ${ }^{36}$

In particular, it is recommended that professional bodies, for instance National Institute for Health Research (NIHR), be tasked to conduct regular evaluation of the performance of national and provincial COVID-19 committees, and report to the officials as well as the public. This will enhance public trust in policymaker and increase people's compliance, which is fundamental to the success of implementing difficult policies, e.g. social distancing and curfew. In addition, such professional bodies may help conduct organized documentation of the experiences at the national and provincial committees, which is crucial to improving the structure and practice of the MoHME governance and performance in the aftermath of the outbreak. This is far beyond the MoHME's recent decision on March, 29 to delegate an individual advisor to conduct documentation. Rather, a systematic wholecapacity approach is essential to fulfill this crucial mission, so evidence-based prevention and planning measures will be documented and available for likely crisis in future. Although the MoHME has established a scientific committee and various UMSs have allocated some budget for research on COVID-19, ${ }^{37,38}$ a systematic approach to evaluation of both policies and measures is still missing. In addition, WHO has compiled a checklist to assess countries' readiness to confront COVID-19 and has also developed some indicators as key performance indicators that assess and evaluate the countries' performance against COVID-19. ${ }^{14}$ The national committee also needs to bring this into the context of decision making.

\section{Discussion}

The pandemic of COVID-19 is perhaps the most devastating global challenge in recent history. As the virus has become a threat to people everywhere, the need for timely, appropriate and cost-effective policies and measures to contain and mitigate its deadly consequences is clear. As described by WHO DG, "We are building the ship as we sail and it is critical that we continue to share learnings and innovations so that we can improve surveillance, prevention, and treatment". ${ }^{21}$ The volume of unknown is significant 
about COVID-19, and despite some similarities among affected countries, the pattern, peak time, doubling time, death rate, etc, have been different. Hence, contextual policy analysis is important to learn from ongoing lessons of the unfolding pandemic, while every single setting needs to tailor its own policies and strategies to manage the outbreak. With WHO at the heart of global coordination for COVID-19, in addition to essential statistics, countries need to demonstrate their own experience, policies and rationale in facing COVID-19 and disseminate them for the benefit of others. WHO recommends that further from the areas where the disease has spread, the need is urgent to develop preparatory policies to fight COVID-19. ${ }^{14,39} \mathrm{In}$ this article, we presented the case of Iran in management of COVID-19 through the lenses of policy and compared its practice with the evidence from China and the WHO. As the novel coronavirus is taking many innocent victims in almost all countries, our aim was to pave the way for effective policy learning and dialogue to reverse this pace.

Responses to the COVID-19 outbreak, at least at the very crucial period of the first few weeks when the virus super-rapidly spreads, have been very diverse in different countries. ${ }^{40}$ These measures range from quarantine of confirmed and possibly infected individuals as implemented in Germany to declaration of lockdown in Italy, France and Spain with individual variations. What is most worrying after all is the danger the virus poses to people already affected by the crisis. ${ }^{21}$ We know from retrospective analysis that travel restrictions can positively impact case development, as observed in the past SARS or Ebola outbreaks. ${ }^{41}$ China's approach in the COVID-19 outbreak exceeds the classic definition of local confinement, lockdown and isolation. With increasing implementation of curfew and lockdown measures in Europe, grave concerns are mounting in the population that previous attempts in handling the COVID-19 spread have been insufficient. ${ }^{42,43}$

Looking at the experience of China and some European countries might let us think that more serious measures should have been taken at the earlier stages to control the epidemic in Iran. ${ }^{44}$ Despite efforts before the official virus arrival, much more preparation as well as containment and mitigation measures were needed in facing COVID-19 in Iran. WHO recommends countries to do the following measures to prevent virus entry: preparing service provider centers, laboratories and health service providers with enough supply of necessary equipment; developing a resource management system, establishing inter-sectoral crisis management workgroups in collaboration with other institutions, informing and educating the community and health service providers, providing training to incoming and outgoing travellers to the infected areas, and providing patient isolation facilities. ${ }^{45}$ As described by WHO DG, the first window of opportunity of the last 1-2 months to prevent COVID-19 entry has been lost in many countries. ${ }^{46}$ Therefore, no country can afford to miss the second window of opportunity to fight the disease. While China is claiming to have successfully managed the outbreak and is gradually ceasing the lockdown in various cities, ${ }^{47}$ Iran is strengthening its measures to make the best use of the second window of opportunity to overcome the challenge.

Comparison between Iran's and China's Measures and Policies in Response to COVID-19 Epidemic

\section{Quarantine and Traffic Restrictions}

China has implemented a series of three-stage targeted actions to combat COVID-19, with the first phase focused on preventing the spread of disease in other cities. It initially quarantined Wuhan, which was the disease epicenter, and extended the policy to other cities depending on their conditions (whether there were single cases, cluster cases, or epidemics), with varying degrees of restrictions on entry and exit. This resulted in the disease not exceeding four provinces by the end of the first stage. ${ }^{48,49}$ One Chinese study used simulation to estimate the impact of quarantine and traffic restrictions on COVID-19 epidemic and reported that by limiting the number of individuals and approaching the quarantine Epsilon index to one, the number of infections decreased by $89.86 \%$. They also showed that by imposing traffic restrictions between provinces, the incidence would be reduced by $21 \%$ to $22 \%$. Therefore, early warning, timely traffic restrictions and quarantine, especially at the start of the epidemic, are very effective, as with one day delay in implementing this policy, approximately 1800 people will be at risk. ${ }^{50}$

Another author argued that Singapore, Hong Kong, Japan and Taiwan, despite being extremely connected with China, reported a very small number of cases. ${ }^{40}$ These countries have taken all measures for containment, using the SARS experience. Containment means ensuring that all patients are identified, controlled, and isolated. Although very late, the recent US move to ban European travel to the country and to close the US-Canada and USMexico border were examples of containment measures. With hundreds of people affected, containment might be no longer effective and measures must be taken for mitigation. Unfortunately, many countries do not have containment skills, so they will inevitably take measures to reduce the impact of the virus. Social distance has been mentioned as the only effective way to this end, ${ }^{51}$ which will reduce the transfer rate below one. ${ }^{52,53}$ This requires the closure of schools, companies, shops, transportation systems, military quarantine, etc. The worse the situation, the more social distance is needed. The sooner the rules of social distance are implemented, the sooner the carriers of the virus are identified and the fewer people will become ill. Italy realized this one day after locking down the Lombardy region and decided to lockdown the whole 
country. Nevertheless, it takes between one and two weeks to observe the consequences of lockdown. ${ }^{40}$

Initially, Iran did not adopt any quarantine or traffic restriction policies (containment or mitigation), which may have led to rapid expansion of COVID-19 in all 31 provinces within two weeks. The country has not adopted a complete lockdown policy so far. Degrees of travel restriction and the gradually increasing business shutdown have been put in place, until March 26, 2020 when the national committee on COVID-19 placed more restrictions to be executed until April 4, 2020..$^{54}$ Based on the Chinese and other experiences, it is recommended that for cities where no case of the disease had been detected, a reverse quarantine should have been performed to prevent virus entry. In cities where outbreaks occur, in addition to reverse city quarantine, quarantine of infected and suspected individuals should be used along with tracking contacts and communications in order to prevent disease entry. In cities where outbreaks or clusters are found, identification and quarantine policies of the cluster should be followed. Finally, in cities such as Tehran, Qom, Rasht, Isfahan, Babol, etc, where large-scale epidemics have occurred, general quarantine of areas (as a single area) should have been applied.

\section{Contact Tracing}

Another key action taken by China was the use of big data technology and artificial intelligence to accurately identify each individual and track their contact interactions with each other. In Wuhan, for example, more than 1800 teams of epidemiologists with at least 5 members in each team track the contact of tens of thousands of people's daily communications. A high percentage of people who were closely related were referred for medical examination and $1-5 \%$ of them had a positive COVID-19 laboratory test. ${ }^{17,55}$ Precise contact tracing of the cases and national patient contact tracing map along with traffic restrictions in Iran are valuable steps in rapid prevention and case identification in Iran. The first official epidemiologic factsheet of COVID-19 cases in Iran was released on Mar 13, 2020.56 The MoHME managed to use its Electronic Health Record portal (SIB) for screening and patient identification on March 5, 2020. Until March $31,2020,65642765$ individuals are reported to have been reached and $3.5 \%$ have been screened as suspicious (in need of further follow-up), while 44606 cases have been positive. Nevertheless, no comprehensive plan has been in place to systematically apply other essential areas of knowledge and technology including psychology, sociology, communication science, health policy, public policy, information technology, etc in the fight against COVID-19. Let alone that frequent changes of front-line commanders in the most conflicted provinces, including Qom and Guilan might have led to unsustainable leadership and sometimes unfavorable outcomes, despite numerous humanitarian scenes of sacrifice by frontline healthcare workforce (i.e. doctors, nurses and allies) to save lives.

\section{Communication Management}

During its peak in Wuhan and priority areas, people were only communicating using WeChat and other online media, purchases were paid online and no one used cash to pay. Even public supplies, such as water, food, etc, were provided online, and people did not have to leave home for basic goods. ${ }^{49}$ Such a policy has not yet been introduced in Iran, while many people continue to interact with each other as they used to. Until March 26, 2020, people were only encouraged to stay home and in voluntary self-quarantine, while there was no law force to ensure the implementation of home stay for contact reduction. Although some policies were in place to minimize people physical contact, e.g. increasing the cap for online and mobile banking and getting cash from ATMs, extending vehicle technical exams for three months, etc, no alternative mechanism was in place to keep people away from workplaces, nor provision of essential needs at the front door had been planned to reduce contact. The MoHME has also designated a specific portal including updated data and guidelines and progress reports in the COVID-19 campaign. ${ }^{56}$

\section{Health Service Provision}

Due to the large number of infected people, many hospital beds in China had to be dedicated to COVID-19 patients. While routine healthcare services did not stop in many places, some elective procedures were postponed. China reports provision of up to $50 \%$ of healthcare services through online and telemedicine technology (smartphones or personal computers), thus freeing more space and capacity to serve COVID-19 patients. ${ }^{49}$ The use of mobile and e-health in Iran has not been advanced, particularly for routine care. ${ }^{13,57}$ However, the use of telemedicine and e-health in emergency situations such as the COVID-19 outbreak could accelerate the process of receiving service and early detection as well as prevent the possible spread of the virus. On February 26, 2020, following the rising trend of new infections and numerous questions and concerns, the MoHME initiated the 4030 call center with 2000 hotlines to respond to people's questions. Moreover, since February 29, the Iranian Health Insurance Organization has allocated 120 phone lines to serve the same purpose. Since March 13, 2020, the SIB portal has been used for screening. People have been recommended to visit the portal and answer simple questions; based on their answers, they are advised not to worry or to carry out further diagnostic or care steps.

China also launched fever clinics. A rapid CT scan was performed if people went to the clinics with fever. If they showed COVID-19 symptoms, further investigations, 
i.e. lab tests or isolation were applied. ${ }^{15}$ Iran enjoys a comprehensive primary healthcare (PHC) network..$^{58}$ Comprehensive community healthcare centers in rural and urban areas in Iran, should have been utilized as the first line in COVID-19 referral system, far beyond the capacity of fever clinics in China. This policy could have prevented crowded hospitals and healthcare providers' burnout, which seem to be serious problems in many front-line hospitals these days. ${ }^{59}$ In addition, China has been regularly updating clinical guidelines, ${ }^{55}$ while increasing its capacity to provide healthcare through high-level coordination with many regions. Over 340 emergency and medical teams and more than 40000 of China's best medical specialists in anesthesia, infectious diseases, lung and cardiovascular disease moved to the Hubei province from other areas of China and effective measures were tailored to each individual in a team of different medical specialties. ${ }^{55}$ Likewise, Iran has been pushing frequent and regular update of standard operational procedures at all levels, while knowledge and evidence on the management of COVID-19 are unfolding.

\section{Coordinated Development of Medical Equipment}

At the start of the epidemic, Hong Kong was in a hurry to find-out laboratory methods to diagnose the disease, and instead of performing diagnostic tests only in one or two laboratories, immediately dispatched the identified technology to the laboratories of all major hospitals. ${ }^{44}$ Although Iran initially suffered from inadequate diagnostic kits and laboratory technology and had to conduct tests only in few labs in Tehran, including the School of Public Health- Tehran University of Medical Sciences and the Pasteur Institute, it increased its capacity in both the number of tests and diversity of labs across the country. As of March 28, 2020, 90 labs in all 31 provinces are capable of conducting specific diagnostic tests everyday, ${ }^{60}$ while inhouse know-how for mass production of kits is in place. ${ }^{61}$

China also coordinated the provision of relevant medical equipment over a short period of time. These included setting up treating mild patients and quarantine centers with a capacity of 4000 beds in 29 hours, utilizing national and regional facilities to increase the capacity to cover needed services such as PCR up to 35000 samples per day. Such measures increased medical resources and capacity. Thus, critically ill patients were admitted to specific hospitals and mild, suspicious, and febrile patients were hospitalized in altered locations. This method has a crucial role in prevention and treatment. ${ }^{55}$ Similar actions have been undertaken in Iran, i.e., the empty capacity of hotels has been used for patients in recovery stages, the country's largest shopping mall in the capital city of Tehran has been turned into a mobile hospital with 3000 beds within one week, while army has transformed the Tehran exhibition center to a mobile hospital with the capacity of 2000 beds during two days.

\section{Conclusion}

The COVID-19 pandemic has become the most devastating global challenge, not only to health but to the whole economy, in recent history. Policies and measures to defeat the pandemic are being made as the virus rapidly pushes the entire globe to a standstill situation. As the volume of the unknown is significant about COVID-19, the need for policy learning, contextual policies and effective strategies to manage the outbreak in various countries is clear. This article presented the case of Iran in management of COVID-19 through the lenses of health policy learning and compared its practice with the evidence from China and WHO. Iran's success in controlling this crisis depends on the extent of applying the whole-government and whole-society approach in formulation, implementation and evaluation of involved policies. Indeed, the pillars of universal health coverage through efficient use of the extensive PHC network and appropriate application of information infrastructure and surveillance systems, are essential for better management of the current pandemic, as well as rebuilding the health system after the crisis.

As the virus is rapidly capturing the entire world with almost one million infected and nearly 50000 casualties in over 200 countries, the need for the highest political support in all countries to manage the crisis and go through the upcoming transitional period is clear. Iran has made many efforts to defeat the outbreak, but more coherent, timely and efficient action is required, now more than ever, to save lives and slow the spread of this pandemic, particularly among the most vulnerable people. As highlighted by WHO DG, "History will judge us on how we responded to the poorest communities in their darkest hour. Let us act together, right now"; tomorrow is too late.

\section{Authors' Contribution}

AT conceived, designed and supervised the study and edited the manuscript. AR conducted data collection and initial analysis and drafted the manuscript. AAS, AO and MA provided experts' opinion and commented on intellectual development of manuscript. $\mathrm{HH}$ contributed in drafting tables and initial data analysis. All authors read and approved the final draft. AT is guarantor.

\section{Conflict of Interest Disclosures}

We have no conflicts of interest to disclose.

\section{Ethical Statement}

This is a document analysis study and does not need ethical approval.

\section{References}

1. Zaki AM, van Boheemen S, Bestebroer TM, Osterhaus AD, Fouchier RA. Isolation of a novel coronavirus from a man with pneumonia in Saudi Arabia. N Engl J Med. 2012;367(19):181420. doi: 10.1056/NEJMoa1211721.

2. Drosten C, Gunther S, Preiser W, van der Werf S, Brodt HR, Becker $S$, et al. Identification of a novel coronavirus in patients with severe acute respiratory syndrome. N Engl J Med. 2003;348(20):1967-76. doi: 10.1056/NEJMoa030747.

3. Cui J, Li F, Shi ZL. Origin and evolution of pathogenic coronaviruses. Nat Rev Microbiol. 2019;17(3):181-92. doi: 10.1038/s41579-018-0118-9 
4. Zhu N, Zhang D, Wang W, Li X, Yang B, Song J, et al. A Novel Coronavirus from Patients with Pneumonia in China, 2019. N Engl J Med. 2020;382(8):727-33. doi: 10.1056/ NEJMoa2001017.

5. Habibzadeh P, Stoneman EK. The Novel Coronavirus: A Bird's Eye View. Int J Occup Environ Med. 2020;11(2):65-71. doi: 10.15171/ijoem.2020.1921.

6. Peeri NC, Shrestha N, Rahman MS, Zaki R, Tan Z, Bibi S, et al. The SARS, MERS and novel coronavirus (COVID-19) epidemics, the newest and biggest global health threats: what lessons have we learned? Int J Epidemiol. 2020. doi: 10.1093/ ije/dyaa033.

7. World Health Organization. Coronavirus disease 2019 (COVID-19): Situation Report-51 WHO; 2020 [updated 2020 Mar 12; cited 2020 Mar 12]. Available from: https://cutt.ly/ qtW0ZpO.

8. Timeline: How the new coronavirus spread. Doha, Qatar: Al Jazeera Media Network; 2020 [cited 2020 Feb 28]. Available from: https://www.aljazeera.com/news/2020/01/timelinechina-coronavirus-spread-200126061554884.html.

9. Ministry of Health and Medical Education, Public Relations and Information Center. [Death of two patient with new coronavirus in Qom]. Tehran: MoHME; 2020. [updated 2020 Feb 19; cited 2020 Feb 19]. Available from: https://cutt.ly/ etWOSIQ.

10. World Health Organization. Coronavirus disease 2019 (COVID-19): Situation Report-31 WHO; 2020 [updated 2020 Feb 20; cited 2020 Feb 20]. Available from: https://www.who. int/docs/default-source/coronaviruse/situation-reports/20200220sitrep-31-covid-19.pdf?sfvrsn=dfd11d24_2.

11. World Health Organization. Coronavirus disease (COVID-19) outbreak situation WHO; 2020 [updated 2020 April 3; cited 2020 Mar 26]. Available from: https://www.who.int/ emergencies/diseases/novel-coronavirus-2019.

12. Takian A, Raoofi A, Kazempour-Ardebili S. COVID-19 battle during the toughest sanctions against Iran. The Lancet. 2020;395(10229):1035-6. doi: 10.1016/s01406736(20)30668-1.

13. Doshmangir L, Bazyar M, Majdzadeh R, Takian A. So near, so far: four decades of health policy reforms in Iran, achievements and challenges. Arch Iran Med. 2019;22(10):592-605.

14. World Health Organization. COVID-19 Strategic Preparedness and Response plan operational; planning guidelines to support country preparedness and response WHO; 2020 [updated 2020 Feb 12; cited 2020 Mar 4]. Available from: https://www. who.int/docs/default-source/coronaviruse/covid-19-sprpunct-guidelines.pdf?sfvrsn=81ff43d8_4.

15. Report of the WHO-China Joint Mission on Coronavirus Disease 2019 (COVID-19). 16-24 February 2020. Available from: https://www.who.int/publications-detail/report-ofthe-who-china-joint-mission-on-coronavirus-disease-2019(covid-19).

16. World Health Organization. A Joint Statement on Tourism and COVID-19 - UNWTO and WHO Call for Responsibility and Coordination WHO; 2020 [updated 2020 Feb 27; cited 2020 Feb 29]. Available from: https://cutt.ly/ptWOHzj.

17. World Health Organization. Coronavirus disease 2019 (COVID-19): Situation Report -42 WHO; 2020 [updated 2020 Mar 3; cited 2020 Mar 3]. Available from: https://www.who. int/docs/default-source/coronaviruse/20200302-sitrep-42covid-19.pdf?sfvrsn=d863e045_2.

18. World Health Organization. WHO team arrives in Tehran to support the COVID-19 response WHO; 2020 [updated 2020 Mar 2; cited 2020 Mar 3]. Available from: http://www.emro. who.int/irn/iran-news/who-team-arrives-in-tehran-to-supportthe-covid-19-response.html.

19. World Health Organization. WHO Director-General's opening remarks at the media briefing on COVID-19 - 5
March 2020 WHO; 2020 [updated 2020 Mar 5; cited 2020 Mar 5]. Available from: https://cutt.ly/6tWOLtt.

20. World Health Organization. Rolling updates on coronavirus disease (COVID-19) WHO; 2020 [updated 2020 Mar 25; cited 2020 Mar 26]. Available from: https://www.who.int/ emergencies/diseases/novel-coronavirus-2019/events-as-theyhappen.

21. World Health Organization. WHO Director General's remarks Launch of Appeal: Global Humanitarian Response Plan - 25 March 2020 WHO; 2020 [updated 2020 Mar 25; cited 2020 Mar 25]. Available from: https://cutt.ly/DtW0Nct.

22. The Global Health Security Index. Global Health Security Index: Building Collective Action and Accountability Washington, DC: Johns Hopkins Center for Health Security; 2019 [updated 2019 Oct; cited 2020 Mar 15]. Available from: https://www.ghsindex.org/wp-content/uploads/2019/10/GHSIndex-Report_FINAL_Oct2019.pdf.

23. Walt G, Shiffman J, Schneider H, Murray SF, Brugha R, Gilson L. 'Doing' health policy analysis: methodological and conceptual reflections and challenges. Health Policy Plan. 2008;23(5):308-17. doi: 10.1093/heapol/czn024.

24. Hall P, Land H, Parker R, Webb A. Change, Choice and Conflict in Social Policy. London: Heinemann; 1975.

25. Buse K, Mays N, Walt G. Making Health Policy. 2nd ed. New York: McGraw-Hill Education; 2012.

26. Sabatier PA, Weible CM. The advocacy coalition framework: Innovations and Clarifications. In: Sabatier PA, ed. Theories of the policy process. USA: Westview Press; 2007. p. 189-220.

27. Alavi Nia M, Ghotbi M, Kermanchi J, Mahdavi Hazaveh A, Nasli Esfahani A, Yarahmadi S. National Program for Prevention and Control of Diabetes Type II in Urban Areas. In: Department of Endocrinology and Metabolic. Center for Non-Communicable Disease Control. Office of Hospital Administration and Clinical Service Excellence. Treatment Deputy. Ministry of Health and Medical Education, editor. Tehran, Iran; 2012.

28. Faraji O, Etemad K, Akbari Sari A, Ravaghi H. Policies and programs for prevention and control of diabetes in Iran: a document analysis. Glob J Health Sci. 2015;7(6):187-97. doi: 10.5539/gjhs.v7n6p187.

29. Lipsky M. Street-Level Bureaucracy: The Dilemmas of the Individual in Public Service. New York, USA: Russell Sage Foundation; 1983.

30. Ripley R, Franklin G. Bureaucracy and Policy Implementation. Homewood, IL: Dorsey; 1982.

31. Zechmeister I, Oesterle A, Denk P, Katschnig H. Incentives in financing mental health care in Austria. The Journal of Mental Health Policy and Economics. 2002;5:121-9.

32. Jenkins-Smith HC, Nohrstedt D, Weible CM, Sabatier PA. The Advocacy Coalition Framework: Foundations, Evolution, and Ongoing Research. In: Sabatier PA, Weible CM, editors. Theories of the Policy Process. 3rd ed. Philadelphia, USA: Westview Press; 2014: 183-224.

33. Fleury M-J, Grenier G, Vallée C, Hurtubise R, Lévesque P-A. The role of advocacy coalitions in a project implementation process: The example of the planning phase of the At Home/ Chez Soi project dealing with homelessness in Montreal. Evaluation and Program Planning. 2014;45:42-9.

34. Lavis JN, Boyko JA, Gauvin F-P. Evaluating deliberative dialogues focussed on healthy public policy. BMC Public Health. 2014;14(1):1287.

35. National Committee on COVID-19 Epidemiology and Iranian CDC, Ministry of Health and Medical Education. [Daily Situation Report on Coronavirus disease (COVID-19) in Iran] Tehran: MoHME; 2020 [updated 2020 Mar 25; cited 2020 Mar 27]. Available from: https://cutt.ly/MtWODbT.

36. World Health Organization. WHO and public health experts conclude COVID-19 mission to Islamic Republic of Iran WHO; 
2020 [updated 2020 Mar 12; cited 2020 Mar 27]. Available from: http://www.emro.who.int/irn/iran-news/delegation-ofwho-and-public-health-experts-concludes-covid-19-missionto-iran.html.

37. Ministry of Health and Medical Education, Deputy of Research and Technology. [National Research and Technology ViceChairs meeting on COVID-19 and Research Considerations] Tehran: MoHME; 2020 [updated 2020 March 11; cited 2020 Mar 27]. Available from: http://www.hbi.ir/forms/newsdetails. aspx? Id=12043\&templateid $=0$.

38. Ministry of Health and Medical Education, Deputy of Research and Technology. [The Minister of Health emphasized the need to carry out comprehensive investigations on Corona] Tehran: MoHME; 2020 [updated 2020 March 10; cited 2020 Mar 27]. Available from: http://www.hbi.ir/forms/newsdetails. aspx? Id =12041 \&hbsld=0\&category $=0$ \&templateid $=0$.

39. World Health Organization. 2019 Novel Coronavirus (2019-nCoV): strategic preparedness and response plan WHO; 2020 [updated 2020 Feb 3; cited 2020 Mar 4]. Available from: https://www.who.int/docs/default-source/coronaviruse/srp04022020.pdf.

40. Pueyo T. Coronavirus: Why You Must Act Now Medium; 2020 [updated 2020 Mar 10; cited 2020 Mar 10]. Available from: https://medium.com/@tomaspueyo/coronavirus-act-today-orpeople-will-die-f4d3d9cd99ca.

41. Errett NA, Sauer LM, Rutkow L. An integrative review of the limited evidence on international travel bans as an emerging infectious disease disaster control measure. J Emerg Manag. 2020;18(1):7-14. doi: 10.5055/jem.2020.0446.

42. Layne SP, Hyman JM, Morens DM, Taubenberger JK. New coronavirus outbreak: Framing questions for pandemic prevention. Sci Transl Med. 2020;12(534). doi: 10.1126/ scitransImed.abb1469.

43. Salathe M, Althaus $C L$, Neher R, Stringhini S, Hodcroft E, Fellay J, et al. COVID-19 epidemic in Switzerland: on the importance of testing, contact tracing and isolation. Swiss Med Wkly. 2020;150:w20225. doi: 10.4414/smw.2020.20225.

44. Beaubien J. The Coronavirus Crisis. Singapore Wins Praise For Its COVID-19 Strategy. The U.S. Does Not. USA: NPR; 2020. [updated 2020 Mar 12; cited 2020 Mar 12]. Available from: URL: https://cutt.ly/ttW0aai.

45. World Health Organization. National capacities review tool for a novel coronavirus WHO; 2020 [updated 2020 Jan 9; cited 2020 Mar 4]. Available from: https://www.who.int/ publications-detail/national-capacities-review-tool-for-anovelcoronavirus.

46. Bloomberg. WHO Has a Simple Message for All Countries: Test, Test, Test [Video]. 2020 Mar 26. Available from: https:// www.bloomberg.com/news/videos/2020-03-16/who-has-asimple-message-for-all-countries-test-test-test-video.

47. Bloomberg. China to Lift Lockdown Over Virus Epicenter Wuhan on April 8 Bloomberg; 2020 [updated 2020 Mar 24; cited 2020 Mar 27]. Available from: https://cutt.ly/mtW0leu.

48. World Health Organization. Novel Coronavirus (2019-nCoV); Situation Report-1 WHO; 2020 [updated 2020 Jan 21; cited 2020 Mar 4]. Available from: https://www.who.int/docs/ default-source/coronaviruse/situation-reports/20200121- sitrep-1-2019-ncov.pdf?sfvrsn=20a99c10_4.

49. WHO Emergencies Coronavirus Press Conference [press release]. World Health Organization; 2020.

50. Li D, Liu Z, Liu Q, Gao Z, Zhu J, Yang J, et al. Estimating the Efficacy of Traffic Blockage and Quarantine for the Epidemic Caused by 2019-nCoV (COVID-19). medRxiv. 2020. doi: 10.1101/2020.02.14.20022913.

51. World Health Organization. Coronavirus disease (COVID-19) advice for the public WHO; 2020 [updated 2020 Mar 18; cited 2020 Mar 27]. Available from: https://www.who.int/ emergencies/diseases/novel-coronavirus-2019/advice-forpublic.

52. World Economic Forum. Coronavirus: This chart shows why social distancing is so important WEF; 2020 [updated 2020 Mar 19; cited 2020 Mar 27]. Available from: https://www. weforum.org/agenda/2020/03/social-distancing-measurescoronavirus-covid19/.

53. Umair I. The math behind why we need social distancing, starting right now VOX; 2020 [updated 2020 Mar 15; cited 2020 Mar 27]. Available from: https://www.vox. com/2020/3/15/21180342/coronavirus-covid-19-us-socialdistancing.

54. Social and Law Committee of COVID-19, Ministry of Interior. [Announcing Social Spatial Plan Details / Zulfiqari: Only residents are allowed to enter cities]. Tehran: Ministry of Interior; 2020. [updated 2020 Mar 27; cited 2020 Mar 27]. Available from: URL: https://www.moi.ir/fa/\%D8\%A7\%D8\% AE\%D8\%A8\%D8\%A7\%D8\%B1/135013.

55. Xiaowei M. Briefing on China's Experience on COVID-19 Response China: vzan; 2020 [updated 2020 Mar 12; cited 2020 Mar 12]. Available from: https://vzan.com/live/tvchat2047457795 ? $v=0.7377976295784845 \#$.

56. Ministry of Health and Medical Education. [National Committee on COVID-19 Epidemiology] Tehran: MoHME; 2020 [updated 2020 Mar 31; cited 2020 Mar 27]. Available from: http://corona.behdasht.gov.ir/.

57. Mousavi SM, Takian A. More value from health IT in low and middle-income countries. Health Policy and Technology. 2020. doi: 10.1016/j.hlpt.2020.02.002.

58. Takian A, Doshmangir L, Rashidian A. Implementing family physician programme in rural Iran: Exploring the role of an existing primary health care network. Family Practice. 2013;30(5):551-9. doi: 10.1093/fampra/cmt025.

59. Iran Islamic Republic News Agency. [Initial evaluation of corona in Tehran comprehensive health centers to reduce referrals to hospitals] Tehran: IRNA; 2020 [updated 2020 March 2; cited 2020 Mar 27]. Available from: https://cutt.ly/ NtWOIKn.

60. Ministry of Health and Medical Education. 990 corona diagnostic laboratory in the country] Tehran: MoHME; 2020 [updated 2020 Mar 28; cited 2020 Mar 27]. Available from: https://cutt.ly/ztOiD27.

61. Ministry of Health and Medical Education, National Medical Device Directorate. [Producing Covid-19 Molecular Diagnosis Kit by Iranian Young Scientists in Danesh Bonyan] Tehran: MoHME; 2020 [updated 2020 March 26; cited 2020 Mar 27]. Available from: https://cutt.ly/YtWOAGK. 